\title{
MOSQUE WITHOUT DOME: CONSERVING TRADITIONAL-DESIGNED MOSQUE IN MELAKA, MALAYSIA
}

Roslan B. Thalib

M. Zailan Sulieman

\author{
School of Housing, Building, and Planning \\ University Sains Malaysia \\ 11800 USM Pulau Pinang Malaysia \\ e-mail: roslantalib@usm.my \\ School of Housing, Building, and Planning \\ University Sains Malaysia \\ 11800 USM Pulau Pinang Malaysia
}

\begin{abstract}
Jasin is one of the area in the state of Malacca in Malaysia, known for its long winding history. Located in the middle seat of government of the Empire of the famous Melaka Sultanate, Jasin district does have a number of quality historic buildings. One of the old buildings found in one the villages located quite close to the town of Jasin is the unique domeless Air Barok Village Mosque. Its location is situated along the main road, easy to reach. In a study stated in this paper, it shows how the unique architecture of this mosque of Air Baroque Village can be appreciated. This paper presents a study of the design elements and architectural features that are unique to the mosque around this region. This paper stated on the approach in creating this structure is different compared to most of the existing mosque currently and previously being built around the state. The concept of neo-archipelago idea to have the Chinese Buddha features in a Muslim mosque was unique found on this religious building located at the side of the world. Expectations for this study to reveal the noble efforts of the Government bodies involved in restoring old buildings such as this mosque can indirectly maintain the cultural arts of the local Malays who are the largest race in Malaysia. Efforts should also be given to maintain old buildings; not only religious buildings but also other building types; in the effort to ensure local arts and culture still exist and can be appreciated by future generations.
\end{abstract}

Keywords: Traditional mosque, conservation, mosque history, Melaka mosque

\begin{abstract}
Abstrak
Jasin merupakan salah satu daerah di negara bagian Melaka di Malaysia yang dikenal karena sejarahnya yang panjang berliku. Terletak tepat di pusat kedudukan pemerintahan Kesultanan Melaka yang terkenal, daerah Jasin memang memiliki sejumlah bangunan bersejarah kualitas. Salah satu bangunan tua yang ditemukan di salah satu desa yang terletak cukup dekat dengan kota Jasin adalah sebuah masjid unik tanpa kubah, yaitu Masjid Desa Air Barok. Lokasinya terletak di sepanjang jalan utama sehingga mudah dijangkau. Dalam sebuah studi dipaparkan apresiasi tentang keunikan arsitektur dari Masjid Desa Air Barok. Tulisan ini menyajikan studi tentang unsur-unsur desain dan fitur arsitektur yang unik bagi masjid di sekitar wilayah ini. Tulisan ini menyatakan pendekatan dalam menciptakan struktur ini berbeda dibandingkan dengan sebagian besar masjid yang ada saat ini dan yang sebelumnya sudah dibangun dibangun di negara itu. Konsep ide neo-archipelago yang memiliki fitur-fitur Buddha - Cina pada masjid Muslim merupakan sesuatu yang unik ditemukan di bangunan religius. Harapan untuk penelitian ini untuk mengungkapkan upaya mulia dari badan pemerintah yang terlibat dalam memulihkan bangunan tua seperti masjid ini yang secara tidak langsung dapat mempertahankan seni budaya lokal Melayu sebagai ras terbesar di Malaysia. Upaya-upaya lainnya juga harus diperjuangkan untuk mempertahankan bangunan tua, tidak hanya bangunan agama, tetapi juga jenis bangunan lain, dalam usaha untuk memastikan seni dan budaya lokal tetap eksis dan dapat dihargai oleh generasi mendatang.
\end{abstract}

Kata kunci: Sejarah masjid, masjid Melaka, masjid tradisional, konservasi

\section{Introduction: History and Background of Air Barok Village}

Air Barok Village is located in the Jasin district. It is located between the Kesang Village and Jasin Town. Map (Figure 5) shows the location of the village on the map. Majority of the population is made up of Malays and some
Chinese and Indians who live near the urban area of Jasin Town. 
Historically, once this area covered by the forest wilderness where at that time no one lived there anymore. They believed that the elderly of their ancestors were once searching for new areas to be created where they will stay-on. Usually, a key component to an appropriate area to be occupied was near the river as a source of basic human needs of food and water resources as well as having forms good topography valley land for settlement and agri- 
culture. In addition, the river is also very important as a means of transportation to get to other destinations.

When their forefathers found the river, there is a group of apes bathing in the river. This resulted in their bath water is called Air Beruk ('beruk' in Malay language means apes) and the name of this village gave the name of the Air Baruk Village. However, there is no clear evidence of this fact. It is found from oral sources from the old people who live there; where they were born after the existence of Air Barok Village. They only heard the oral stories from their parents who maybe born after the exis- tence of this village.

Moreover, there is also an opinion mentioned that the village has been pioneered by Datuk Senara who are also act as Jasin Town chieftain. However, this theory has no clear evidence to determine the authenticity. Perhaps this is the conclusion of the old residents of this village is said to be confused with Datuk Senara's grave in the town of Jasin, located close to the village. It is possible that if this statement is true; Datuk Senara can be the most important person in the development of the Air Barok Village and also the development of Jasin Town.

\section{The Original Proposals of Air Barok Village Mosque}

From the observation of several interviews with the villagers, the mosque was built in 1916. 1916 is stated at the gate's wall of this mosque (Figure 1) further strengthen this statement. However, in an interview made with Haji Ahmad Yunus, who was born in 1917 and Haji Saadon Haji Yahaya, who was born in 1936; the date stating the existence of this mosque is much earlier because the fence were built many years before the mosque main building has been built (maybe between 1914).

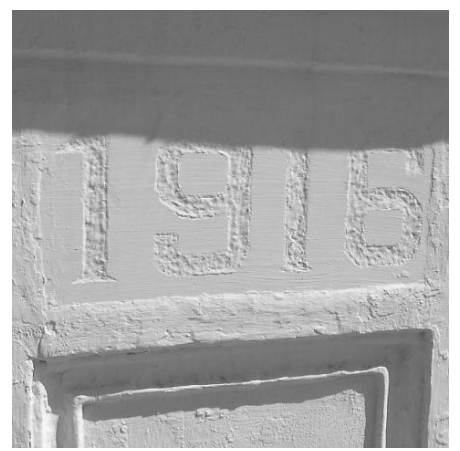

Figure 1. Date (1916) written on the walls of the Air Baruk Mosque gates

However, this statement cannot be confirmed because there is no concrete evidence of this fact. From this interview, it is known that the mosque was built by wealthy people who donated the site where the mosque was built, namely Haji Babu (Figure 2 ). He is known as a rich urban folks and well-known to the nearby villages such as the village of Chin Chin where he lived, and Air Barok Village and also Rim Village (Figure 3).

Through the interviews made with several residents who still live in the village of Chin Chin, one of them is Mrs. Zaharah Haji Babu. Haji Babu is a Singh become a noble man after converted to Islam after some time living in Kesang area. He came from India to Malacca on board the barge and stop-by in Kesang. He began work there as fishermen and sell them to a barge carrier where he was used to be with. He was only 12 years old at that time. From there he saved some money and started a timber business and his timber business become larger.

He died at the age of 106 years; during that time Madam Zaharah was at her five yearold. The story of Haji Babu is known through the story of the mother of the youngest wife of Haji Babu that he made his wealth bit by bit and bought quite some number of land. Haji Babu believed to have many wives. Each child will be given the land as proper-ty. For the wife who had not having children being given compensation and then he divorced her. This is because he is believed to be a conscious descent.

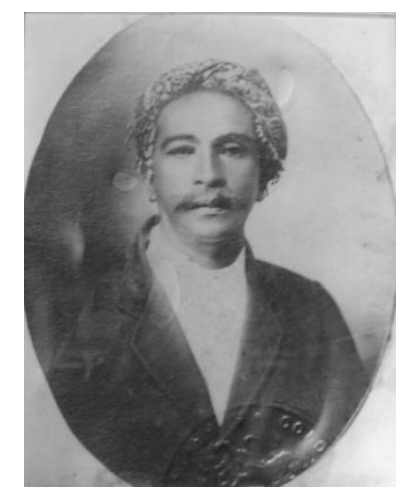

Figure 2. Haji Babu Bin Abdullah (Source: Mrs. Zaharah Haji Babu)

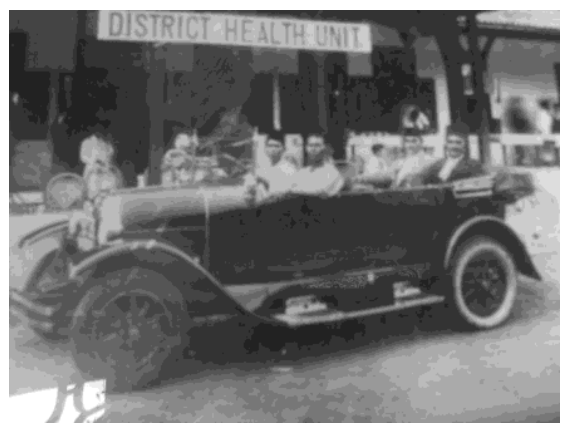

Figure 3. Haji Babu with his followers

Haji Babu led the planning for the construction of this mosque in collaboration with several other 
wealthy people who lived near the area. From an interview with Tan Sri Aziz Tapa (a well known local political veteran), the material of the construction of this mosque ie the tiles, was bought by Haji Babu from Medan, Sumatera. These building materials are those of the collapsed Deli Palace in Sumatera. However the mosque's marbles are believed to be brought from Italy and are believed to be purchased for the construction of the mosque. According to the villagers again, the construction of belian pillars (belian is the type of local timber) is in addition to supporting the roof; is donated from unidentified wealthy person. Namely, each belian columns have their own donors who supported the construction of those belian pillars.

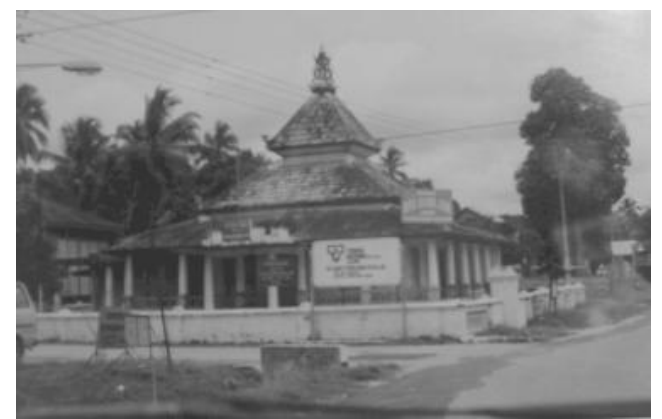

Figure 4. Air Barok Village Mosque was found by the Department of Museum Antiquities that is not used anymore in 1989

From observations made on the old map of Jasin Town, this mosque also known as Old Jasin Town Mosque. Therefore, it can be concluded that this mosque is the center of religious activities in this urban areas and the surrounding villages before the construction of other mosques. In addition to re- ligious activities, the mosque is also used for Friday prayers congregation by local residents. Activities of Air Barok Village Mosque was active until the main Jasin Jamek Mosque was constructed and completed located nearby; within the city of Jasin. This is because the expand of local population resulting in demand for more praying space.

Therefore, the mosque is no longer used for congregational prayers but only used for regular prayer time only. But still, there are classes to study the Quran at the mosque. However, after islamic school building beside it was built, the mosque is not used anymore. This is according to Mr. Isnordin from the Department of Antiquities told that the mosque is not in use yet when they make a visit in 1989 (Figure 4) to lead the proposed conservation work that has been done in early 2000.
Site of Air Barok Village Mosque, Maintenance Rights, and Construction Development

Air Barok Village Mosque is located on the outskirts of the road to the Kesang-Jasin Town trunk road. There is a restaurant located in front of the mosque and a religious school is located on the left, and the back is made up of residential houses; the traditional Malay houses (Figure 5).

Through interviews conducted with Tuan Haji Mohd. Meni; Mosque Chairman; the mosque site as stated before are the property of Haji Babu. It cannot continue been endowed/wakaf to the villagers until it was transferred after three generations of hereditary. At first, Haji Babu nominated down the land ownership of the land to his son named Haji Abu, and later to another son named Haji Ahmad took over ownership rights. On a sense of responsibility, Haji Ahmad was keep the corpus of land site location of this mosque to the public.

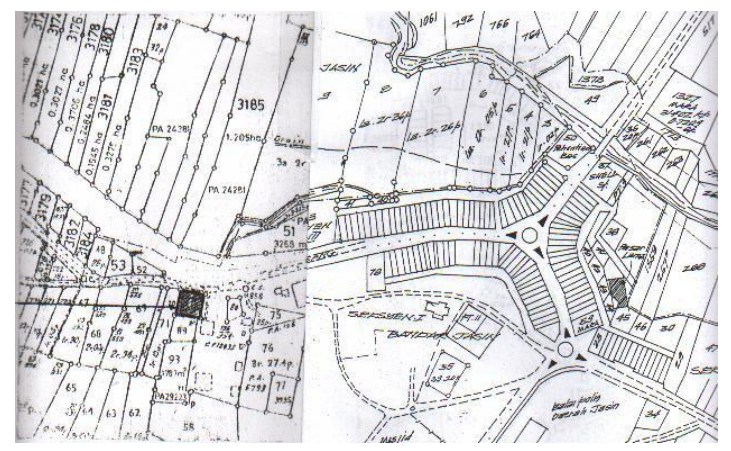

Figure 5. The location plan Air Barok Village Mosque, shown in dark square (Source: City Council of Jasin)

The mosque was guarded and managed by the members of the Mosque Committee. There is an additional building of the original design to be used as a classroom to study the Koran. There are also additional pits constructed for the purpose of ablution place for those who establish regular prayers there.

\section{Structural Analysis and Components Structure of Air Barok Village Mosque}

In the construction of a mosque, few aspects of the structures should be taken into account. For example, based on the area around it, the influence of construction and building materials must be appropriate during that construction period. This aspect is important because it is the aspect that distinguishes the mosque with other buildings. Among are the preparation of the roof, pulpit, sanctuary, prayer room, pits, walls, towers, and so forth. 


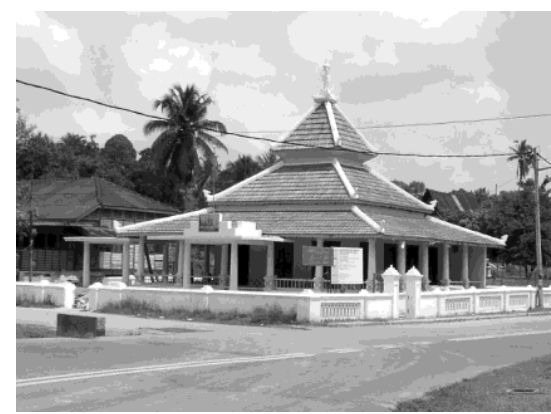

Figure 6. Masjid Kampung Air Baroque, as it is now

There is a major component in the construction of a mosque as described in this analysis report which is the main components of the mosque. Analysis made on this mosque is based on a heritage survey provided as guidance by Badan Warisan Malaysia (Malaysia Heritage Board). From the analy- sis made, Air Barok Village Mosque has heritage features and the architecture of the mosque cons- tructed within the Nusantara Archipelago vocabu- lary. The building was undergoing conservation work and retention of original design by the Department of Museums and Antiquities (see Figure 6). In terms of suitability to the climate, the roof rise and there is some kind of louvers around the façade to facili- tate the process of building ventilation. The orienta- tion before the Qiblah (in Mecca, Saudi Arabia) which is a common principle used in the construction of each of the mosques. Hopefully, further metric study of this Air Barok Village Mosque will be made and described in the next section study.

\section{Building Context}

The mass of the mosque is shaped in such a way having a tiered roof. It is an example of the main elements of the architecture of building of a mosques in Melaka. A view of certain corner of the mosque are shows on this picture below (Figure 7 -

9).

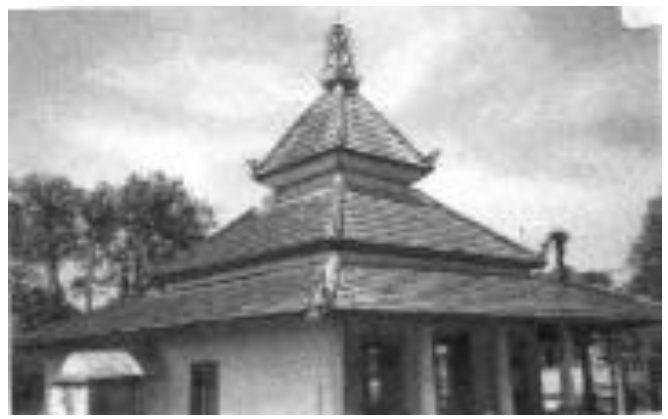

Figure 7. Angular view of Air Barok Village Mosque

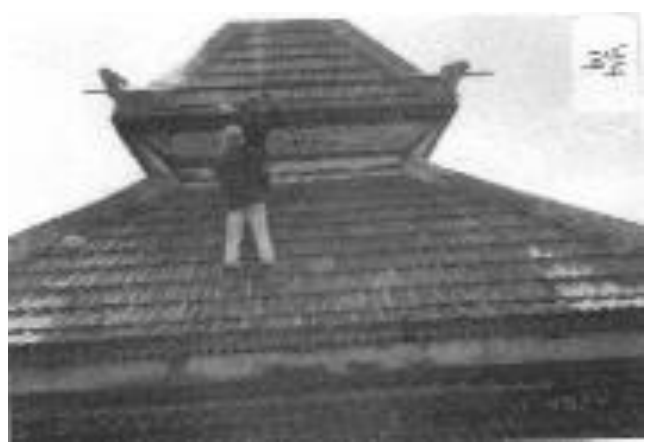

Figure 8. View towards the upper part of Air Barok Village Mosque

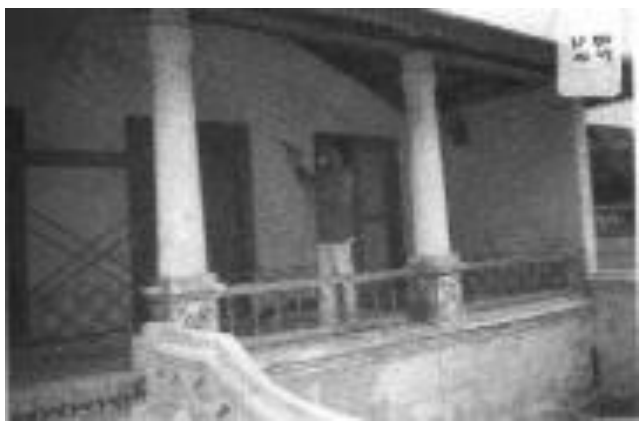

Figure 9. The Verandah; side view of Air Barok Village Mosque

\section{Plan}

In plan, the mosque shape is square and is surrounded by a porch on each 'façade' except the 'façade' facing the Qaaba direction that is adjusted to the roof. There are certain principles to plan the shape of this square as in relation to the design philosophy on Traditional Malay archipelago Mosque. Air Barok Village Mosque building is the size of approximately 20 meter wide and long.

\section{Building Modules}

Building module is comprised of five parcels (five bay) and not linked to any other building. The verandah (anjung) is the first and last compartment and the second through fourth compartment is the prayer hall. If look in plan mode, the building have a strip of buildings that made-up the mosque building module. The mosque height is one and a half higher of the typical building height.

\section{Basis of Buildings}

Foundation used in this building is the foundation of the strip type. This can be seen from the drawings provided by architects who was in charge of the conservation work of this mosque. 
Wall

Building material for wall base (foundation wall material) and the wall of the raw material used is concrete bricks in the outer plaster. In addition, the wall which is also decorated with a tile pattern (Figure 10). Tile material is originated from Italy and have certain privileges.

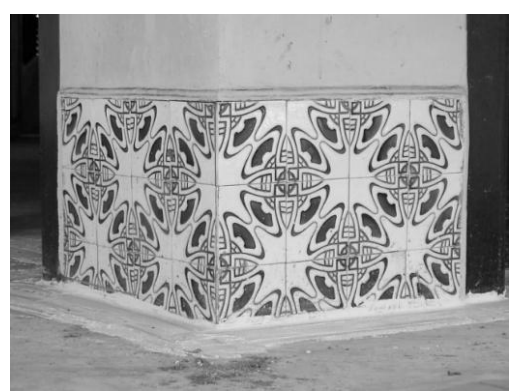

Figure 10. Finishes the beautiful tiles on the bottom of the concrete wall

Pillar

There are two types of columns/pillars in the mosque. The four pillars of the belian type (the term for the pillars supporting the roof of every mosque in Archipelago/Nusantara region) (Figure 11) on the inside of the mosque is decorated with a concrete pillar with tile pattern on its whole surface. For columns on the porch located outside; also having decorative feature at the bottom of the concrete pillar (Figure 12).

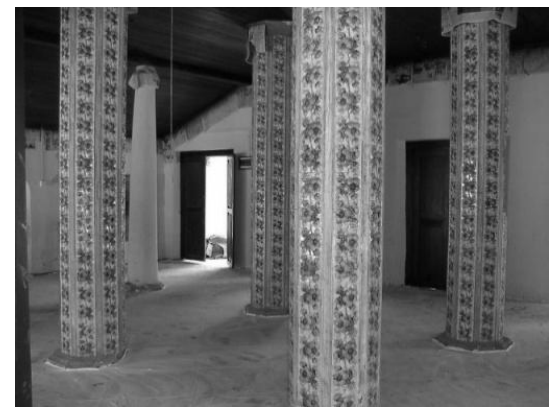

Figure 11. The belian pillar pole tidy-up with colorful floral motive tiles designed as a whole

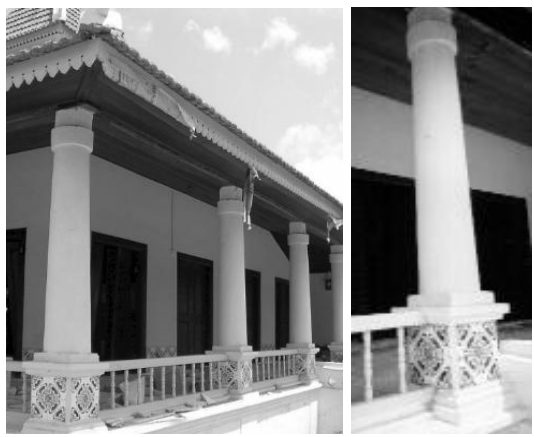

Figure 12 . On the porch column

\section{Outside the Open Verandah}

There is an open verandah area at the mosque around the sides and front facade. It is surrounded by 'balustrade' of concrete and several columns as described above (Figure 13). There are also front yard installed with terracotta flooring at the outside of the building.

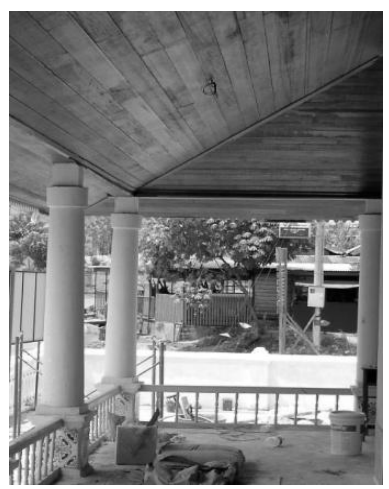

Figure 13. Mosque of Air Barok's porch

\section{Roof}

This is the type of roof mosque called roof Meru. In terms of suitability to the climate, the roof rise should facilitate the process of ventilation. But the function of roof ventilation components to suit the installation does not work because there is a ceiling on the mosque. Roof design is based on the architectural design of mosques in the Archipelago that uses elements of the tiered roof ventilation agent. Due to the lack of understanding; the function of this multilevel roof design used in this mosque shows the image without emphasizing the function of design. Finishes on the roof is from pieces of roof tiles called 'marsile' made from clay (Figure 14). The fascia board of the building made of the board with engraved pattern.

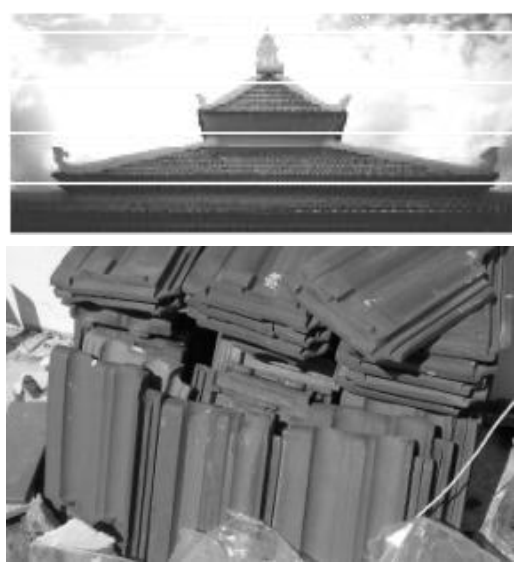

Figure 14. Roof of the Mosque Air Barok Village (above) and materials used (below) 


\section{Crown}

Crown (instead of dome) is the most special item for each Traditional Melaka/Malacca Mosque. Like other mosques of Malacca which is consisted of three levels of the ridge, the crown is one of the arts of the Malays who poured into the sacred building. Each level represents a certain level. Air Barok Village Mosque crown is made of concrete materials. If you see this section in the mosque of Air Barok there is Buddhist influence in its design. The pattern form resemblance of the modified abstracted dragon image (Figure 15).

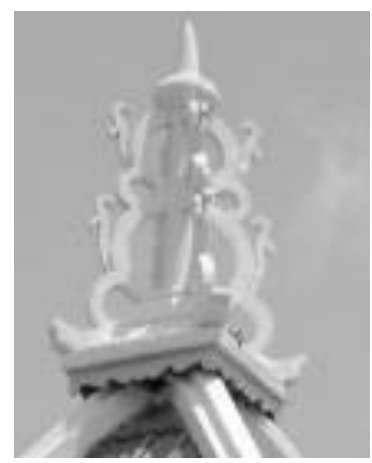

Figure 15. The Crown Air Barok Village Mosque

\section{Ridge/'Salur Bayung'}

The 'Salur Bayung' of Air Barok Village Mosque is in the same shape with other traditional mosques in Melaka. Its 'Salur Bayung' is made of concrete. The 'Salur Bayung' feature is inspired from the stem were taken from a wild plant in the water. It also reflects the first time of 'tahhiyat' in the prayer. If carefully viewed; in this 'bayung' stem; one can noted that the image of a pagoda in the design of this mosque. This view enhanced the fact that design elements of the mosque have influenced of the Buddha in it (Figure 16).

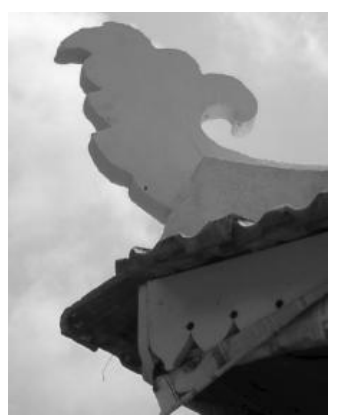

Figure 16. Stem/'Salur Bayung' at Air Barok Village Mosque

\section{Windows and Doors}

Windows are shaped with non-decorative elements and its finishes leaving flat surface (Figure
17). Similarly, the door of the mosque is in the form of an empty flat and finish with flat board.

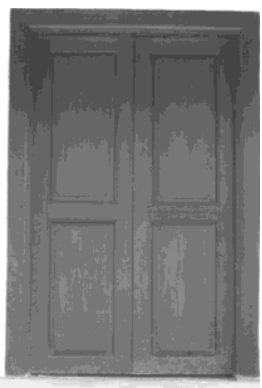

Figure 17. The detail of the window

\section{Floor}

Floor finishes are of a large marble tiles. It was bought from Italy as explained earlier (Figure 18 and 19).

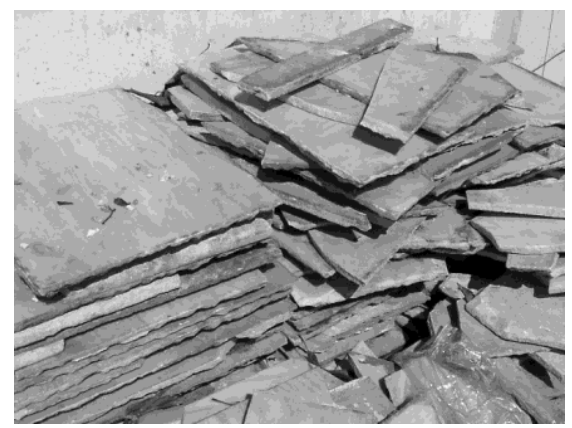

Figure 18. Original marble tiles as floor finishes being removed

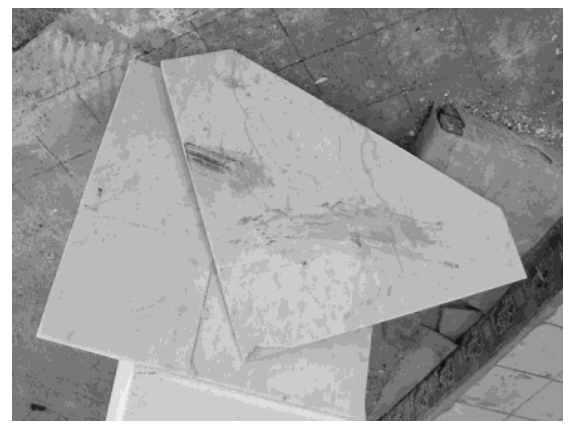

Figure 19. New marble tiles used as floor finishes

\section{Chamber/Mihrab}

The place where the imam led the prayers in congregation is shaped by the dome (arch), which indicates the direction of the Qiblah. This mosque's Mihrab deviated slightly from the big prayer hall space (Figure 20). The said area can be seen clearly in Figure 21 which show the views behind the mosque (Figure 21). There is no natural light or ventilation here because there are no openings. Building materials are the same with wall materials of the mosque. 


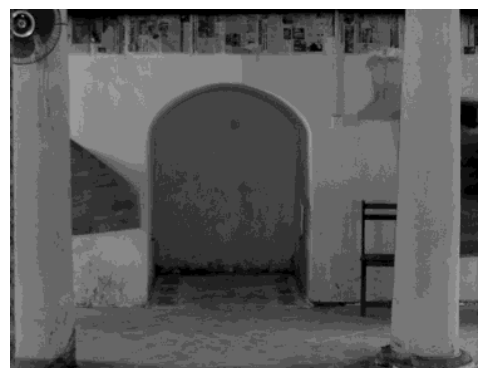

Figure 20. The views of the mosque sanctuary

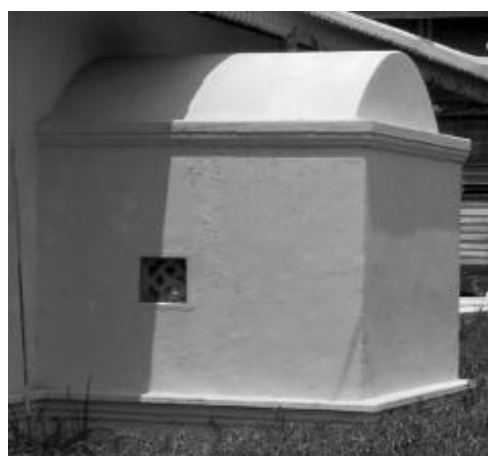

Figure 21. External view of the sanctuary of the mosque

\section{Pulpit/Mimbar}

For the pulpit, the mosque has decorated ceiling decorated with interesting sculptures become an important component of the mosque and became a preacher sermon during the weekly Friday Prayer (Figure 22).

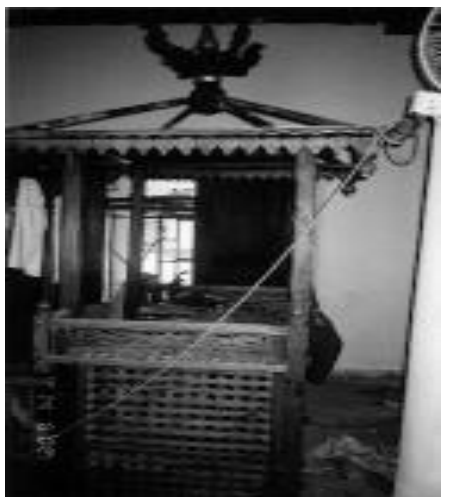

Figure 22. Air Barok Village Mosque pulpit

\section{Pits/'Kolah'}

Not the original structure of the mosque. Built to enable more pilgrims to perform ablution before prayer been made together, especially the Friday prayers. Materials consist of concrete construction with ceramic tiles (Figure 23).

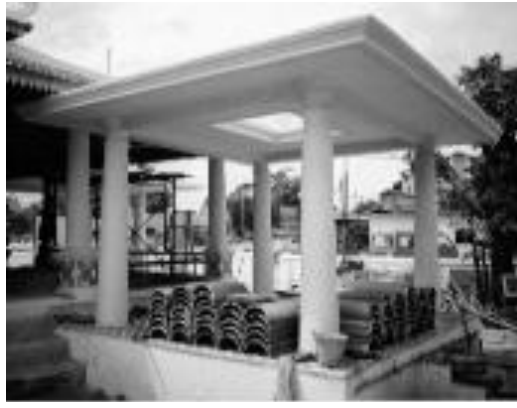

Figure 23. The pits at the mosque

Well

These wells are used for ablution before the pits been build or after the wells has been constructed, the pits are no longer in use. Well construction materials that are cylindrical brick plaster is unique to show the beauty of the bricks used as construction materials (Figures 24, 25).

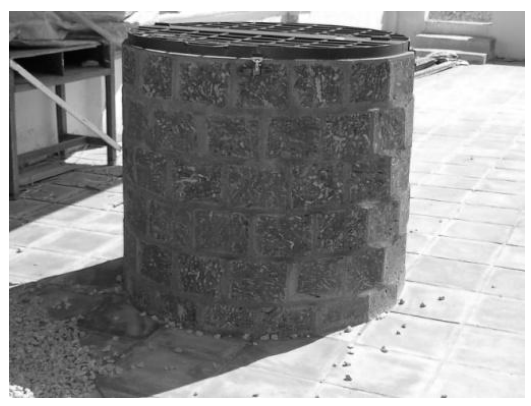

Figure 24. Water wells of the Air Barok Village Mosque

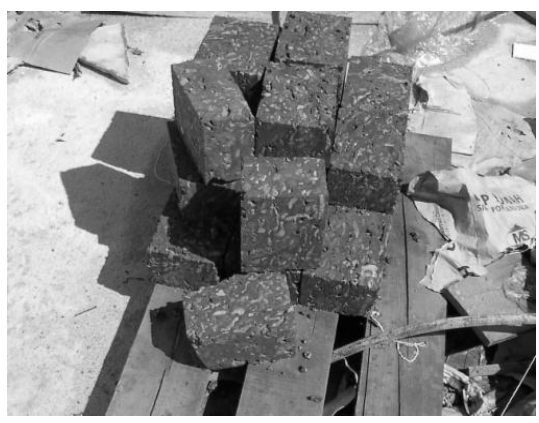

Figure 25. Construction materials used as well finish

\section{Main Door/Gate}

The mosque gates are made of concrete materials (Figure 26). It seems to invite more people to come with an attractive concrete stairs decorated with tiles designed to attract. The roof is a flat roof made of concrete. There is also the another secondary entrance (Figure 28) of the fence around the mosque. 


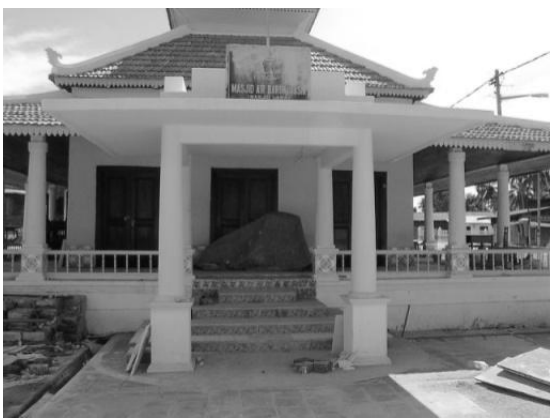

Figure 26. The main entrance of mosque

Stairs

Like the concept of traditional Malay houses are commonly found in Melaka, treated as the aesthetic elements to invite guests in its design. Similarly with this mosque, this types of the concrete stairs is having very exciting finish tiles seem to invite people in the mosque. At the main entrance, the stairs (Figure 27) seems longer compared to the side entrance and the main entrance's stairs having special features and design finishes. This is possible because there are strong elements of the main gate entrance to show-off. In contrast to the more hidden stairs located on side entrance, the design steps (Figure 28) is less interesting in term of its design finishes tiles.

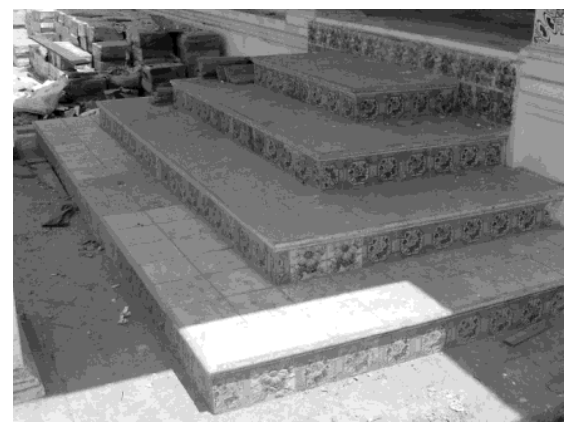

Figure 27 . The stairs at the main gate

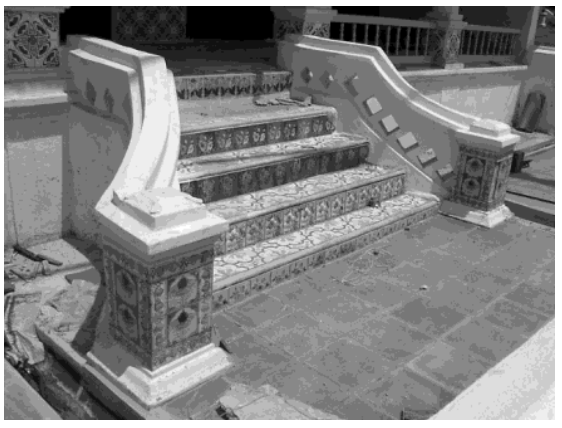

Figure 28. Stairs at the entrance of the mosque side

\section{Preliminary Conclusion}

Conclusions from this analysis, found that the mosque has a distinctive architectural beauty preserved by the conservation projects undertaken by the Department of Museums and Antiquities. Conservation project will allow the architecture of Air Barok Village Mosque is appreciated on its retention of original form.

With typical mosques around the world to make the dome as the main element, the Mosque of Air Barok Village is a unique show with no dome. Its design is more akin to the influence of Chinese Buddhism. The oriental influences on its architectu- ral design show the kind of traditional Malay mosque

which still can be found around this particular region. This mosque must be retained to its original form as to highlight the uniqueness of the vernacular mosque architecture for future generations to admire.

\section{References}

1 M. Brett and W. Forman. 1980. The Moors: Islam in the West. London: Orbis Publishing.

2 Voon F. Chen. 1998. The Encyclopedia of Malaysia. Archipelago Press.

3 P. Davies. 1987. Splendours of the Raj: British Architecture in India 1660-1947. Middlesex: Penguin Books.

4 Mohd. Tajuddin Mohd. Rasdi. 2001. Identiti Senibina Malaysia. Penerbit UTM.

5 A.H Nasir. 1984. Mosques of Peninsular Malaysia. Kuala Lumpur: Berita Publishing Sdn. Bhd.

6 A.H Nasir. 1987. Traditional Malay Wood Carving. Kuala Lumpur: Dewan Bahasa dan Pustaka.

7 K. Yeang. 1992. The Architecture of Malaysia. Amsterdam: The Pepin Press. 